\title{
Effect of human atrial natriuretic peptide on blood pressure after sodium depletion in essential hypertension
}

\author{
W M T JANSSEN, P E de JONG，G K vaN DER HEM， D de ZEEUW
}

\begin{abstract}
Human atrial natriuretic peptide was infused over four hours in three patients with essential hypertension. When the patients had a sodium intake of $200 \mathrm{mmol}(\mathrm{mEq})$ daily an infusion of $0.5 \mu \mathrm{g}$ atrial natriuretic peptide/min caused no significant change in blood pressure, whereas an infusion of $1.0 \mu \mathrm{g} / \mathrm{min}$ caused a gradual decrease in blood pressure and an increase in heart rate. After two to three hours of infusion with the higher dose two patients showed a sudden decrease in heart rate, with symptomatic hypotension. When the same patients had an intake of 50 mmol sodium daily their blood pressure was more sensitive to infusion of atrial natriuretic peptide; one patient again developed symptomatic hypotension, this time during an infusion of $0.5 \mu \mathrm{g} /$ min. During all infusions distinct natriuresis occurred irrespective of whether blood pressure was affected.

Prolonged, relatively low dose infusions of atrial natriuretic peptide can cause unwanted symptomatic hypotension. The effect on blood pressure is enhanced after sodium depletion, and blood pressure should be monitored carefully during longer infusions of atrial natriuretic peptide in patients with essential hypertension.
\end{abstract}

\section{Introduction}

Atrial natriuretic peptides induce a decrease in blood pressure. Most studies have reported the effects of either bolus injections of atrial natriuretic peptide, ${ }^{1}$ or infusions for 30 to 60 minutes. ${ }^{23}$ The antihypertensive response in those studies was quite different. In addition to the different modes of administration of atrial natriuretic peptide the state of the renin-angiotensin-aldosterone system might

\footnotetext{
Department of Medicine, Division of Nephrology, State University Hospital, Groningen, The Netherlands

W M T JANSSEN, MD, research fellow

P E DE JONG, MD, nephrologist

G K VAN DER HEM, MD, professor of nephrology

D DE ZEEUW, MD, medical staff

Correspondence and requests for reprints to: Dr P E de Jong, Department of Medicine, Division of Nephrology, State University Hospital, 9713 EZ Groningen, The Netherlands.
}

play a part. ${ }^{+}$We therefore studied the effects of long infusions of various doses of atrial natriuretic peptide under two conditions of sodium balance in patients with essential hypertension.

\section{Patients and methods}

Human atrial natriuretic peptide dissolved in $5 \mathrm{~g}$ mannitol/100 ml (L-346 670, MSDRL, Rahway, New Jersey, United States) was infused at different doses $(0.125,0.25,0.5$, and $1.0 \mu \mathrm{g} / \mathrm{min})$ in three patients with essential hypertension (two men and one woman aged 35-54 with diastolic blood pressure $>100 \mathrm{~mm} \mathrm{Hg}$ and normal renal function). For at least two weeks before the study the patients did not take any drugs and received a diet containing $200 \mathrm{mmol}$ (mEq) sodium daily. Two days before the first infusion of atrial natriuretic peptide they were admitted to hospital, where they had absolute bed rest and received a constant daily intake of sodium and fluid until the end of the study. The infusions of atrial natriuretic peptide were then repeated after a two week run in period, during which the patients received $50 \mathrm{mmol}$ sodium daily.

During the study the patients adhered to a rhythm diet consisting of equal amounts of sodium, potassium, and liquids every two hours. Blood pressure was recorded continuously at two minute intervals from 1000 to 1800 with a non-invasive automatic device (Dinamap). Urine was collected by spontaneous voiding every hour from 0800 to 1800 . Baseline values were measured from 1000 to 1200 , and from 1200 till 1600 atrial natriuretic peptide or placebo (solvent) was infused. Measurements were confirmed till 1800.

\section{Results}

Placebo infusions resulted in a variation of blood pressure from $+4 \%$ to $-7 \%$ during the periods of both high and low salt intake. During the diet of $200 \mathrm{mmol}$ sodium daily an infusion of $1.0 \mu \mathrm{g}$ atrial natriuretic peptide $/ \mathrm{min}$ initially induced a gradual decrease in blood pressure of about $10 \%$ and an increase in heart rate (fig 1). After two to three hours, however, blood pressure suddenly decreased in cases 1 and 3 , with a concomitant decrease in heart rate. These two patients had severe symptoms of hypotension with cold sweating and dizziness, and the infusion had to be stopped. Symptoms resolved within a few minutes, and blood pressure gradually increased again. In contrast, no decrease in blood pressure or even a pressure response occurred during the infusion of $0.5 \mu \mathrm{g}$ atrial natriuretic peptide/min. Natriuresis was induced by both doses.

When the patients had a daily intake of $50 \mathrm{mmol}$ sodium, however, the infusion of $0.5 \mu \mathrm{g}$ atrial natriuretic peptide/min caused a significant decrease in blood pressure. A hypotensive response similar to that observed after the infusion of $1.0 \mu \mathrm{g} / \mathrm{min}$ during the high sodium intake was observed again in 
Case 1

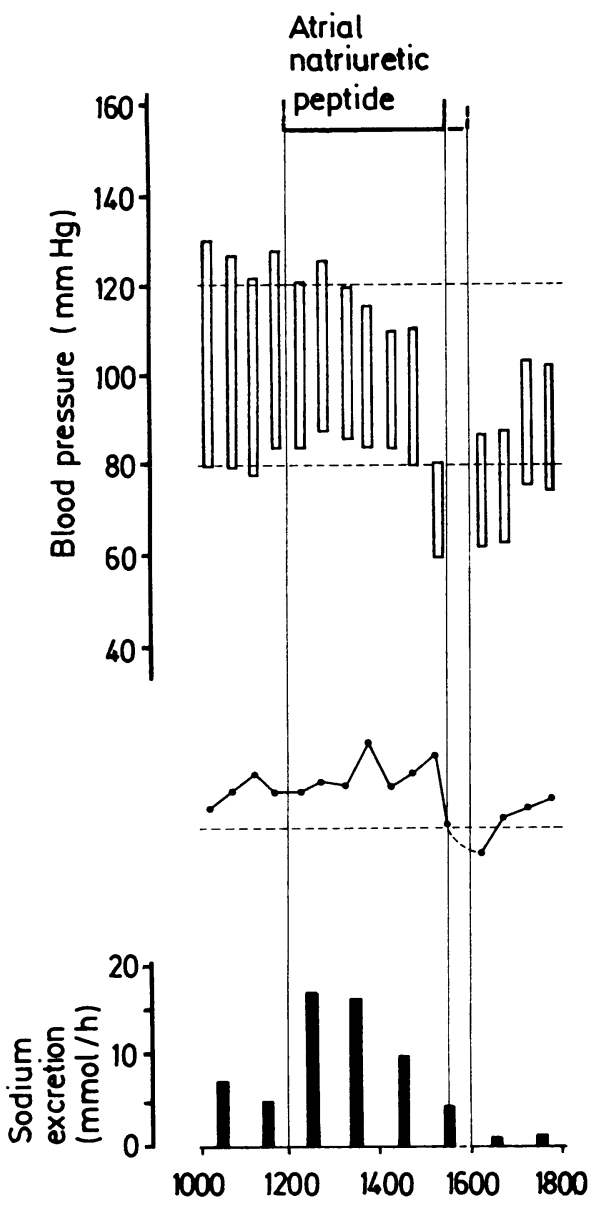

Case 2

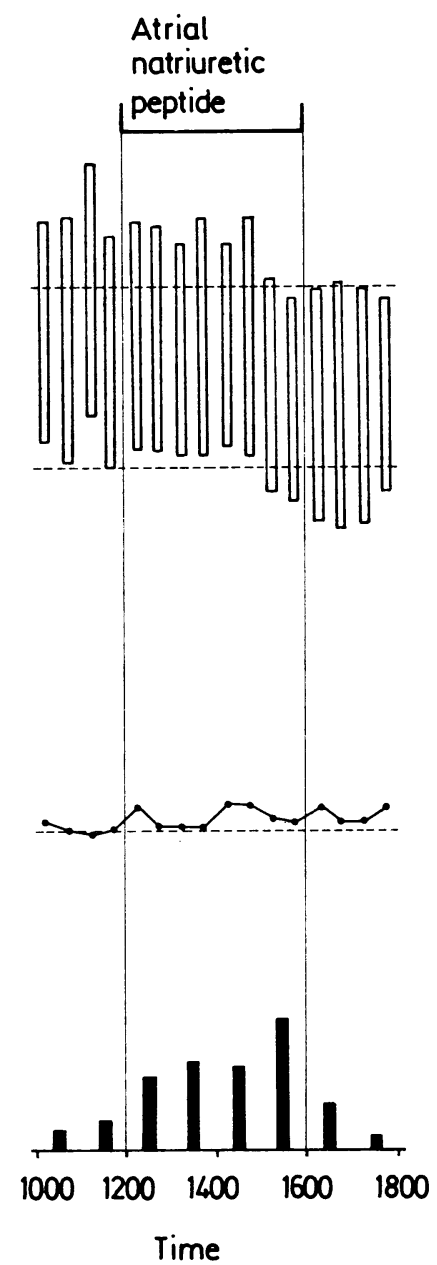

Case 3

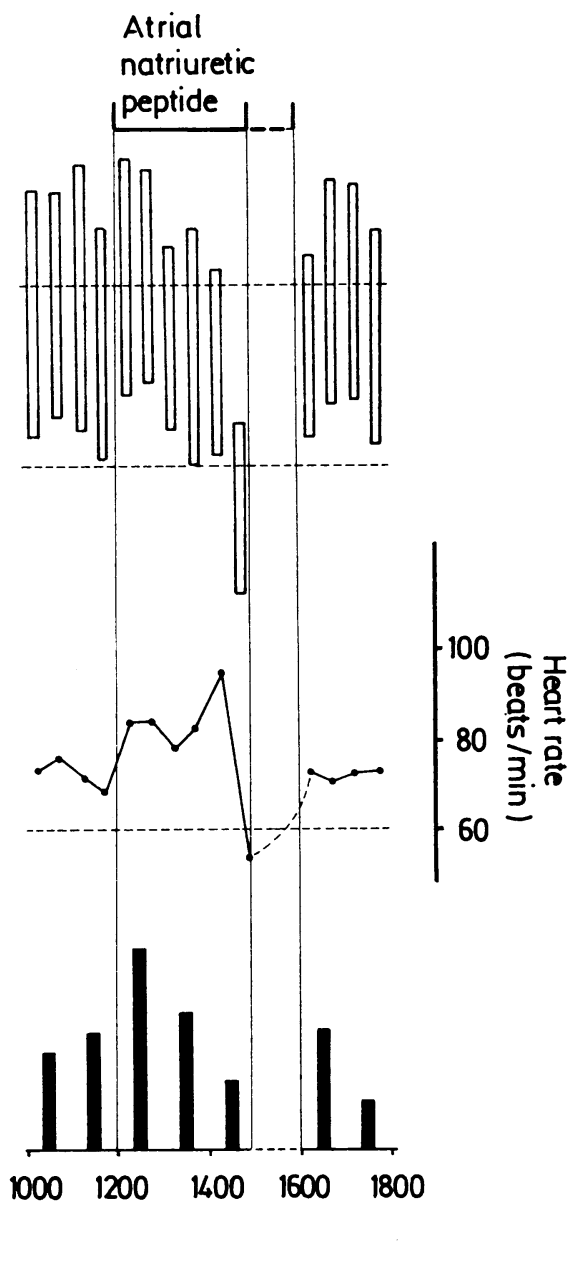

FIG 1 -Effects of $1.0 \mu \mathrm{g}$ atrial natriuretic peptide/min on blood pressure and heart rate (means of 15 measurements over 30 minutes) and sodium excretion during diet of $200 \mathrm{mmol}$ sodium daily in three patients with essential hypertension. (Values directly before infusion was stopped in cases 1 and 3 are means of three recordings taken at one minute intervals.)

case 1 after two and a half hours of infusion. The effect on blood pressure of infusions of $0 \cdot 25$ and $0 \cdot 125 \mu \mathrm{g} / \mathrm{min}$ during this low sodium diet was less pronounced. A dose-response curve for both sodium intakes was constructed (fig 2); during low sodium intake the curve shifted to the left. At the low sodium intake natriuresis was again observed at all doses of atrial natriuretic peptide.

\section{Discussion}

The gradual decrease in blood pressure and increase in heart rate, initially observed during the infusion of $1.0 \mu \mathrm{g}$ atrial natriuretic peptide/min in patients receiving a high salt intake, is characteristic of treatment with a vasodilator and is compatible with data from animal experiments. ${ }^{5}$ After two to three hours, however, the heart rate suddenly fell in parallel with a severe hypotensive collapse (fig 1). Such an occurrence has not, to our knowledge, been reported previously. Other workers have used bolus injections of $100 \mu \mathrm{g}$ atrial natriuretic peptide or infusions of $3 \mu \mathrm{g} / \mathrm{min}$ for 30 to 60 minutes without observing symptomatic hypotension. ${ }^{23}$ The difference in duration of administration of atrial natriuretic peptide might be responsible for our observation; a cumulative effect of atrial natriuretic peptide is less likely as it is rapidly metabolised. ${ }^{3}$

We showed that salt depletion increases the effect of atrial natriuretic peptide on blood pressure (fig 2). This emphasises the potential risk of infusion of atrial natriuretic peptide in essential hypertension. Even low doses that do not influence the blood pressure during high salt intake cause a hypotensive collapse during low salt intake. Because of the pronounced and reproducible
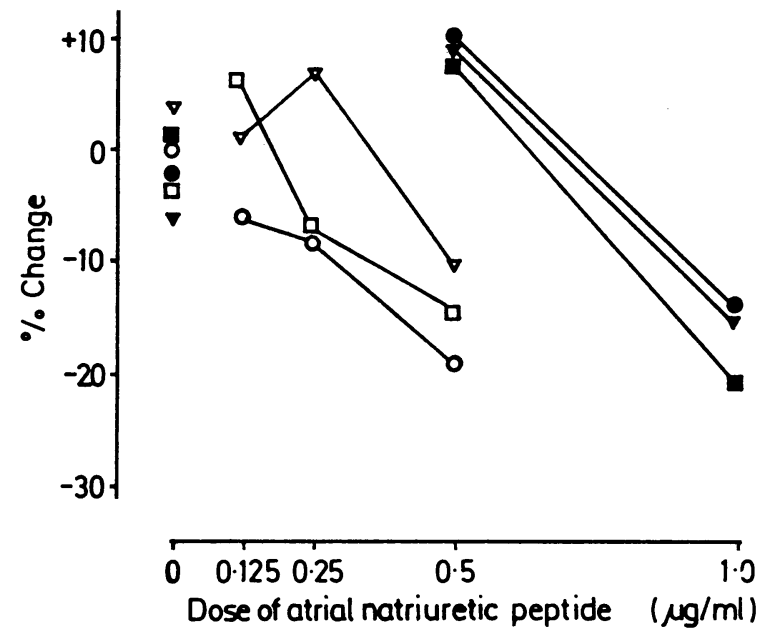

FIG 2-Percentage change in diastolic blood pressure at end of infusion of atrial natriuretic peptide plotted against infusion dose. Black symbols indicate data obtained during high sodium diet; open symbols indicate data obtained during low sodium diet. $O / O=$ Case $1 ; \nabla / \nabla=$ case $2 ; \square / \square=$ case 3 .

symptomatic hypotension that we observed no more patients were enrolled in this study. During all infusions of atrial natriuretic peptide, even at doses that did not decrease blood pressure, sodium excretion increased, suggesting that it is not only natriuresis that is responsible for the change in blood pressure. 
We conclude that atrial natriuretic peptide can induce a gradual decrease in blood pressure, sometimes followed by symptomatic hypotension, which occurs suddenly. This phenomenon depends on the duration of the infusion as well as the dose. Moreover, the dose effect is enhanced during low sodium intake. This warrants careful observation of patients with essential hypertension who are given infusions of atrial natriuretic peptide over longer periods.

We thank M J Gomez and E S Otterbein from Merck, Sharp, and Dohme Research Laboratories for their support.

\section{References}

1 Richards AM, Nicholls MG, Ikram H, Webster MWI, Yandle TG, Espiner EA. Renal haemodynamic, and hormonal effects of human alpha atrial natriuretic peptide in healthy volunteers. Lancet 1985 ; i:545-9.

2 Tikkanen I, Fyhrquist F, Metsrinne K, Leidenius R. Plasma atrial natriuretic peptide in cardiac disease and during infusion in healthy volunteers. Lancet 1985;ii:66-9.

3 Espiner EA, Crozier IG, Nicholls MG, Cuneo R, Yandle TG, Ibram H. Cardiac secretion of atrial natriuretic peptide. Lancet 1985;ii:398-9.

4 Volpe M. Odell G, Kleinert HD, et al. Effect of atrial natriuretic factor on blood pressure, renin and aldosterone in Goldblatt hypertension. Hypertension 1985;7:143-8.

Ackermann U Irizawa TG, Milojevic S, Sonnenberg H Cardiovascular effects of atrial extracts in anesthetized rats. Can f Physiol Pharmacol 1984;62:819-22.

(Accepted 8 May 1986)

\title{
The effect of desmopressin on nocturnal polyuria, overnight weight loss, and morning postural hypotension in patients with autonomic failure
}

\author{
CHRISTOPHER J MATHIAS, PAUL FOSBRAEY, \\ DAVID F DA COSTA, \\ ANDREW THORNLEY, ROGER BANNISTER
}

\begin{abstract}
Day and night urine volume, morning and evening body weight, and supine and sitting blood pressure were measured in five patients with chronic autonomic failure who were not receiving treatment with drugs. All had nocturnal polyuria, overnight weight loss, and a pronounced postural fall in blood pressure, with lowest levels in the morning. Desmopressin (2-4 $\mu \mathrm{g}$ given intramuscularly at $8 \mathrm{pm}$ ) reduced nocturnal polyuria, diminished overnight weight loss, raised supine blood pressure, and reduced the postural fall, especially in the morning, when patients were often at their worst.

Desmopressin may be a useful alternative to, or may supplement, other forms of treatment in some patients with autonomic failure.

\section{Introduction}

Patients with autonomic failure often find that their symptoms of postural hypotension are worse in the morning. Their blood pressure is often lowest at this time ${ }^{1}$ and this may be related to nocturnal polyuria, which probably reduces the volume of extracellular fluid. To investigate this we studied patients before and after reversal of nocturnal polyuria with an antidiuretic agent, desmopressin.
\end{abstract}

\section{Patients and methods}

Six patients with progressive autonomic failure (four men and two women, aged between 55 and 68 ) were studied; two also had multiple system

\footnotetext{
Medical Unit, St Mary's Hospital Medical School, Paddington, London W2 1PG and University Department of Clinical Neurology, Institute of Neurology, Queen Square, London

CHRISTOPHER J MATHIAS, DPHIL, MRCP, Wellcome senior lecturer in medicine and honorary consultant physician

PAUL FOSBRAEY, PHD, research assistant

DAVID F DA COSTA, MRCP, research fellow

ANDREW THORNLEY, MSC, research assistan

SIR ROGER BANNISTER, DM, FRCP, consultant neurologist

Correspondence to: Dr Mathias, St Mary's Hospital Medical School.
}

atrophy. ${ }^{2}$ All had severe sympathetic failure and symptomatic postural hypotension. Drugs (fludrocortisone acetate and ephedrine) had been withdrawn three days previously. Their intake of fluid and food was unrestricted, and they maintained their normal level of mobility. Urine was collected over periods of 12 hours ( $9 \mathrm{am}$ to $9 \mathrm{pm}$ and $9 \mathrm{pm}$ to $9 \mathrm{am}$ ), and volume, osmolality, and excretion of sodium and potassium were measured. Patients were weighed at 9 am and $9 \mathrm{pm}$. Blood pressure (mercury sphygmomanometer) and heart rate (radial pulse) were measured after the patients had been supine for at least 10 minutes and after they had been sitting on the edge of the bed for two minutes. Standing blood pressure was not recorded because some found it difficult to stand, particularly in the morning. Measurements were taken before meals to avoid postcibal hypotension. ${ }^{3}$ On the third day haemoglobin concentration, packed cell volume, blood urea, plasma sodium and potassium concentrations, and plasma osmolality were measured. After three control days the observations were repeated, with the addition of $2 \mu \mathrm{g}$ desmopressin given intramuscularly at $8 \mathrm{pm}$ on the first night, followed by $4 \mu \mathrm{g}$ for two further nights. Blood measurements were repeated after three days' treatment with desmopressin. Patients then either restarted their previous treatment or entered a pilot study to determine a beneficial therapeutic dose of intranasal desmopressin. Five patients who completed the study are analysed here as a group and one patient is discussed separately as she developed hyponatraemia. Paired and unpaired $t$ tests were used for statistical analysis. Results are expressed as means (SEM).

\section{Results}

\section{CONTROL PERIOD}

All patients had nocturnal polyuria, with an overnight excess of 169 (79) $\mathrm{ml}$ (table I). Overnight weight loss was $0.74(0.07) \mathrm{kg}(\mathrm{p}<0.01)$. Nocturnal urinary sodium concentration was greater $(p<0.05)$ and urinary osmolality was lower than during the day. Supine blood pressure was lowest in the morning and rose during the day (table II). The postural fall in blood pressure on sitting was similar in the morning and evening, but symptoms were worse in the morning, probably because supine blood pressure was lower.

\section{DESMOPRESSIN PERIOD}

After treatment with desmopressin there was a pronounced reduction in nocturnal polyuria $(p<0.01)$ (see table I) and overnight weight loss was reduced. Body weight rose by $1.35(0.06) \mathrm{kg}(\mathrm{p}<0.01)$ over three days. Supine blood pressure was higher in the morning (see table II), when the postural fall was maximally reduced $(p<0.05)$. Sitting blood pressure improved during the day. Overnight urinary osmolality was higher $(p<0.05)$ 